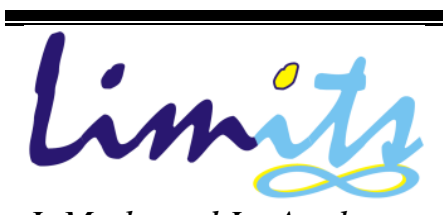

J. Math. and Its Appl.

E-ISSN: 2579-8936

P-ISSN: $1829-605 \mathrm{X}$

Vol. 15, No. 2, Nopember 2018, 151-166

\title{
Konstruksi dan Analisis Dinamik Model Matematika Sistem Penangkapan Ikan (Studi Kasus Pelabuhan Perikanan Nusantara Brondong)
}

\author{
Nailul Izzati ${ }^{1} *$, Imamatul Ummah ${ }^{2}$ \\ ${ }^{1,2}$ Fakultas Teknik Universitas Hasyim Asy'ari Jombang Indonesia \\ e-mail: nailulizzati@unhasy.ac.id ${ }^{1}$, imamatulummah@unhasy.ac.id ${ }^{2}$
}

\begin{abstract}
Abstrak
Penangkapan ikan berlebihan di Laut Jawa menyebabkan populasi ikan terus menurun. Untuk menangani hal ini, diperlukan sosialisasi dan kajian terkait sistem penangkapan ikan. Penelitian ini bertujuan untuk mengkonstruksi model matematika sistem penangkapan ikan yang mengacu pada kondisi Pelabuhan Perikanan Nusantara Brondong Kabupaten Lamongan. Model matematika yang telah dikonstruksi kemudian dianalisis kestabilannya dengan menggunakan kriteria Routh-Hurwitz. Analisis kestabilan menunjukkan bahwa model matematika yang dikonstruksi memiliki tiga titik kesetimbangan, yaitu titik kesetimbangan trivial, titik kesetimbangan tanpa penangkapan ikan dan titik kesetimbangan bioekonomis. Ketiga titik kesetimbangan yang diperoleh bersifat stabil bersyarat. Simulasi numerik menunjukkan bahwa tanpa tindakan penangkapan, populasi ikan dapat menjadi tidak seimbang, sedangkan penangkapan ikan yang tidak terkondisikan, yakni yang tidak memenuhi syarat kestabilan titik kesetimbangan bioekonomis, dapat mengakibatkan kepunahan ikan.
\end{abstract}

Kata Kunci: analisis kestabilan, kriteria Routh-Hurwitz, model penangkapan ikan.

\begin{abstract}
Overfishing in Java Sea causes a great decline of the fish population. To deal with this problem, socialization and further study about fish harvesting system are required. The objective is to construct mathematical model of fish harvesting system that refers to the condition of Pelabuhan Perikanan Nusantara Brondong Kabupaten Lamongan. The constructed model are analyzed by Routh-Hurwitz criteria. The results showed that the model has three equilibriums, i.e. trivial, non-harvesting and bioeconomic ones. Those equilibriums are conditionally stable. Numerical simulations showed that without fish harvesting, the fish population could be unbalance, while the unconditioned fish harvesting could cause the fish extinction.
\end{abstract}

Keywords: fish harvesting model, stability analysis, Routh-Hurwitz criteria.

\section{Pendahuluan}

Laut Jawa memiliki potensi mencapai 836.000 ton per tahun. Eksploitasi terhadap potensi ikan di Laut Jawa dinilai berlebihan. Menurut Kepala Bidang Perikanan Tangkap Dinas Kelautan dan Perikanan Jawa Timur, Eryono, eksploitasi terhadap potensi ikan Laut Jawa telah mencapai 95 persen dari total populasi yang ada, sehingga hanya tersisa 5 persen bagi generasi yang akan 
datang [1]. Di Kabupaten Lamongan, data kapal bongkar di Pelabuhan Perikanan Nusantara Brondong mencatat setidaknya 65.373 ton ikan ditangkap pada tahun 2017 oleh nelayan setempat [2], jumlah ini belum termasuk hasil tangkapan daerah lain.

Salah satu upaya pencegahan eksploitasi berlebihan terhadap sumber daya laut dilakukan pemerintah dengan mengeluarkan Peraturan Menteri Kelautan dan Perikanan Nomor 2 Tahun 2015 tentang larangan penggunaan alat tangkap pukat hela dan pukat tarik, termasuk di dalamnya adalah alat tangkap cantrang yang digunakan oleh mayoritas nelayan yang berlabuh di Brondong. Hingga tahun 2018, peraturan tersebut belum sepenuhnya dapat diterapkan karena nelayan merasa dirugikan secara sosial dan ekonomi. Oleh karena itu, diperlukan sosialisasi dan studi lebih lanjut tentang dampak penangkapan ikan secara berlebihan dan kajian solusinya.

Penelitian tentang perlindungan populasi ikan telah dilakukan dan masih terus dikembangkan dengan berbagai sudut pandang. Mulai dari dinamika kebijakan perikanan [3], dinamika oseanografi terhadap hasil tangkapan ikan [4] sampai pemodelan matematika kondisi stok ikan di perairan [5] dan penangkapan ikan. Berangkat dari model predator-prey LotkaVolterra [6] dapat dibangun berbagai model matematika tentang penangkapan ikan. Diantaranya adalah model penangkapan ikan dengan fungsi respon yang bergantung pada prey [7], [8], dan prey-dan-predator [8], model penangkapan ikan di area perairan dilindungi [9], [10], model reaksi dinamis sistem predator-prey dengan tingkatan usia pada predator [11], [12], model biomatematis dengan pemilihan ikan tangkap [10], dan dampak aturan maximum sustainable yield pada sistem predator-prey [13].

Tujuan dari penelitian ini adalah mengkonstruksi sebuah model matematika yang menggambarkan sistem penangkapan ikan dengan mempertimbangkan adanya interaksi predatorprey bertingkat pada populasi ikan, serta hasil tangkapan ikan oleh nelayan. Analisis kestabilan kemudian dilakukan untuk mengetahui perilaku variabel-variabel pada sistem. Terakhir, dilakukan simulasi numerik untuk mengetahui perilaku sistem.

\section{Metode Penelitian}

Tahap-tahap yang dilakukan pada penelitian ini adalah konstruksi model, analisis kestabilan, dan simulasi numerik. Konstruksi model dilakukan dengan membentuk sistem persamaan diferensial yang merepresentasikan sistem penangkapan ikan oleh nelayan yang berlabuh di Pelabuhan Perikanan Nusantara Brondong Kabupaten Lamongan. Analisis kestabilan dilakukan dengan menggunakan kriteria Routh-Hurwitz [14]. Untuk melakukan analisis kestabilan, mulamula dicari titik kesetimbangan sistem dan matriks Jacobinya. Titik kesetimbangan yang diperoleh kemudian disubstitusikan ke dalam matriks Jacobi sehingga didapatkan persamaan karakteristik. 
Dari koefisien-koefisien persamaan karakteristik dibentuk tabel kriteria Routh-Hurwitz. Titik kesetimbangan sistem disebut stabil jika tidak terdapat perubahan tanda pada kolom pertama tabel kriteria Routh-Hurwitz. Simulasi numerik dilakukan dengan metode Runge-Kutta Order Empat [15] dan menggunakan software MATLAB.

\section{Hasil dan Pembahasan}

Pada bagian ini dibahas konstruksi model, analisis kestabilan dan simulasi numerik model matematika sistem penangkapan ikan oleh nelayan yang berlabuh di Pelabuhan Perikanan Nusantara Brondong.

\subsection{Konstruksi Model}

Menurut data kapal bongkar Pelabuhan Perikanan Nusantara Brondong, terdapat 35 jenis ikan hasil tangkapan nelayan yang menggunakan alat tangkap cantrang. 35 jenis ikan tersebut adalah Alu-alu/Kucul, Togek/Ayam-ayam, Balak/Beloso, Banyar, Baronang/Sadar, Bawal Hitam/Dorang, Bentol/Lencam, Biji Nangka/Jenggot, Bukur/Jaket, Cucut, Cumi-cumi, Grobyak/Ikan Sebelah, Gulama/Tiga Wajah/Tetet, Kakap Merah/Bambangan, Kapasan, Kembung, Kerapu, Kerong-kerong/Kerok, Kuniran, Kurisi, Kwee Putihan, Layang, Layur, Lemadang, Lemuru, Manyung, Mata Besar/Swanggi, Pari/Pe, Peperek/Dodok, Selar, Tembang/Juwi, Tenggiri, Tonang/Cendro/Remang, Tongkol, dan Campuran [16]. Jika jenis-jenis ikan tersebut diasumsikan terbagi menjadi tiga golongan, yaitu prey, predator tingkat I, dan predator tingkat II, maka posisi ketiganya dalam rantai makanan dapat diilustrasikan dengan Gambar 1. Semua jenis ikan yang berada di tingkatan paling bawah rantai makanan diasumsikan sebagai prey, yaitu Togek, Balak, Banyar, Baronang, Bawal Hitam, Bentol, Biji Nangka, Bukur, Cumi-cumi, Gulama, Kapasan, Kembung, Kerong-kerong, Kuniran, Kurisi, Kwee Putihan, Layang, Lemuru, Mata Besar, Peperek, Selar, Tembang, Tongkol, dan Campuran. Sedangkan semua jenis ikan yang memangsa prey diasumsikan sebagai predator tingkat I, yaitu Grobyak, Kakap Merah, Kerapu, Layur, Lemadang, dan Manyung. Dan semua jenis ikan yang memangsa predator tingkat I adalah predator tingkat II, yaitu Alu-alu, Cucut, Pari, Tenggiri, dan Tonang.

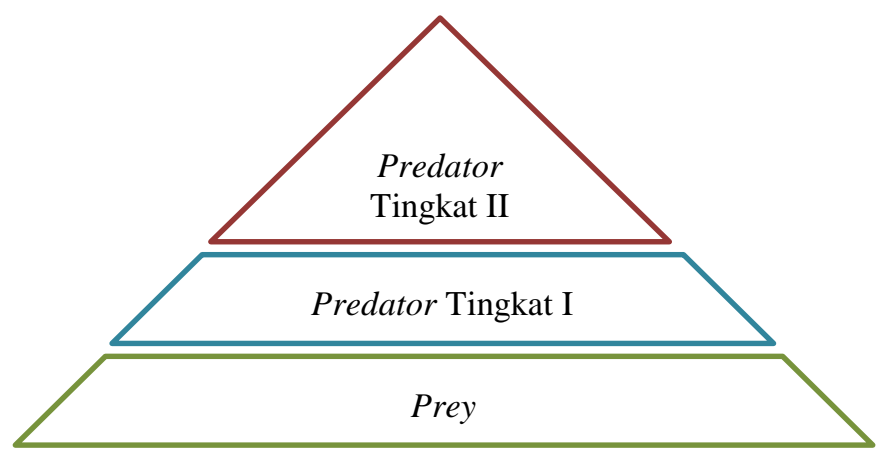


Gambar 1 Piramida Rantai Makanan

Model yang dikonstruksi mempertimbangkan empat buah variabel, yaitu populasi prey $(P)$, predator tingkat I $(Q)$, predator tingkat II $(R)$, dan hasil penangkapan ikan $(E)$. Berdasarkan studi literatur, pengumpulan data Pelabuhan Perikanan Nusantara Brondong dan hasil wawancara dengan nelayan sekitar, berikut adalah beberapa asumsi yang digunakan dalam konstruksi model:

1. Perubahan populasi prey dipengaruhi oleh persamaan logistik,

2. Prey adalah mangsa dari predator tingkat I, sedangkan predator tingkat I adalah mangsa dari predator tingkat II. Tidak terdapat kanibalisme dalam rantai makanan,

3. Terdapat kematian alami pada predator tingkat I dan tingkat II,

4. Ikan yang ditangkap oleh nelayan adalah semua jenis ikan (prey, predator tingkat I, dan predator tingkat II),

5. Laju penangkapan ikan diasumsikan sebagai rasio antara total tangkapan ikan per tahun dengan potensi ikan Laut Jawa per tahun,

6. Hasil penangkapan ikan merupakan selisih dari hasil penjualan ikan dan biaya operasional yang dibutuhkan untuk melaut, kedua hal ini dipengaruhi oleh stiffness coefficient,

7. Harga jual ikan diperoleh dari nilai rata-rata harga jual dari ketigapuluhlima jenis ikan tangkapan,

8. Biaya operasional dan waktu melaut diasumsikan sama untuk tiap keberangkatan kapal nelayan.

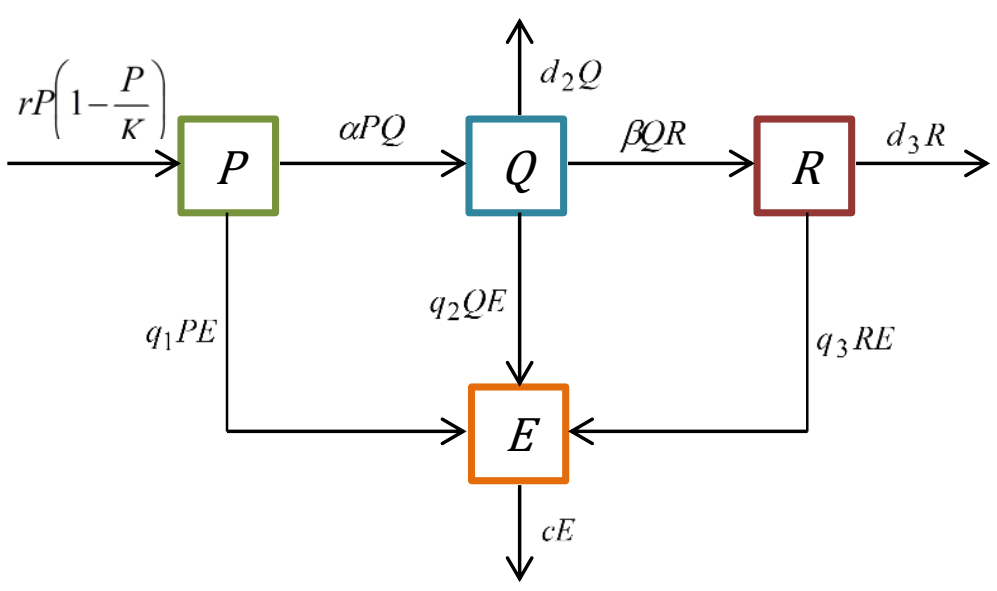

Gambar 2 Diagram Kompartemen Model Matematika Sistem Penangkapan Ikan

Dengan mempertimbangkan asumsi-asumsi tersebut, dapat dibangun sistem persamaan diferensial yang menggambarkan sistem penangkapan ikan oleh nelayan Lamongan yang 
diberikan oleh sistem persamaan (1)-(4). Interaksi antara keempat variabel pada model disajikan dengan diagram kompartemen pada Gambar 2.

$$
\begin{aligned}
& \frac{d P}{d t}=r P\left(1-\frac{P}{K}\right)-\alpha P Q-q_{1} P E \\
& \frac{d Q}{d t}=\alpha P Q-d_{1} Q-\beta Q R-q_{2} Q E \\
& \frac{d R}{d t}=\beta Q R-d_{2} R-q_{3} R E \\
& \frac{d E}{d t}=\gamma\left[p\left(q_{1} P+q_{2} Q+q_{3} R\right)-c\right] E .
\end{aligned}
$$

dengan

$r$ : laju kelahiran prey,

$K$ : carrying capacity,

$\alpha$ : laju pemangsaan prey oleh predator tingkat I,

$\beta$ : laju pemangsaan predator tingkat I oleh predator tingkat II,

$\gamma:$ stiffness coefficient,

$d_{1}$ : tingkat kematian alami predator tingkat I,

$d_{2}$ : tingkat kematian alami predator tingkat II,

$q_{1}$ : laju penangkapan prey,

$q_{2}:$ laju penangkapan predator tingkat I,

$q_{3}$ : laju penangkapan predator tingkat II,

$p$ : harga jual ikan,

$c$ : total biaya operasional yang dibutuhkan oleh nelayan untuk melaut.

\subsection{Titik Kesetimbangan}

Titik kesetimbangan dari sistem (1)-(4) diperoleh dengan menyelesaikan persamaan $\frac{d P}{d t}=\frac{d Q}{d t}=\frac{d R}{d t}=\frac{d E}{d t}=0$. Penyelesaian persamaan $\frac{d P}{d t}=\frac{d Q}{d t}=\frac{d R}{d t}=\frac{d E}{d t}=0$ menghasilkan tiga titik kesetimbangan dari sistem (1)-(4), yaitu titik kesetimbangan trivial $T(0,0,0,0)$, titik kesetimbangan tanpa tindakan penangkapan ikan $T^{0}\left(P^{0}, Q^{0}, R^{0}, 0\right)$ dan titik kesetimbangan bioekonomis $T^{*}\left(P^{*}, Q^{*}, R^{*}, E^{*}\right)$, dengan

$$
P^{0}=\frac{K}{r}\left(r-\alpha \frac{d_{2}}{\beta}\right), Q^{0}=\frac{d_{2}}{\beta}, R^{0}=\frac{1}{\beta}\left(\alpha \frac{K}{r}\left(r-\alpha \frac{d_{2}}{\beta}\right)-d_{1}\right),
$$




$$
\begin{aligned}
P^{*} & =\frac{K}{r}\left(r-\frac{\alpha}{\beta}\left(d_{2}+q_{3} E^{*}\right)-q_{1} E^{*}\right), Q^{*}=\frac{d_{2}+q_{3} E^{*}}{\beta}, \\
R^{*} & =\frac{\alpha K}{\beta r}\left(r-\frac{\alpha}{\beta}\left(d_{2}+q_{3} E^{*}\right)-q_{1} E^{*}\right)-\frac{d_{1}}{\beta}-\frac{q_{2}}{\beta} E^{*}, \\
E^{*} & =\frac{p\left(q_{1} K \beta^{2} r-q_{1} K \alpha \beta d_{2}+q_{2} d_{2} \beta r+q_{3} \alpha K \beta r-q_{3} \alpha^{2} K d_{2}-q_{3} d_{1} \beta r\right)-c \beta^{2} r}{p\left(2 q_{3} q_{1} \alpha \beta K+q_{1}{ }^{2} \beta^{2} K+q_{3}{ }^{2} \alpha^{2} K\right)} .
\end{aligned}
$$

Titik kesetimbangan bioekonomis adalah titik kesetimbangan yang memungkinkan adanya aspek biologi dan ekonomi. Dalam hal ini, dimungkinkan adanya penangkapan ikan, namun populasi ikan tetap ada.

\subsection{Kestabilan Titik Kesetimbangan}

Matriks Jacobian dari sistem persamaan (1)-(4) diberikan oleh matriks (5),

$$
J(P, Q, R, E)=\left[\begin{array}{cccc}
j_{1} & -\alpha P & 0 & -q_{1} P \\
\alpha Q & j_{2} & -\beta Q & -q_{2} Q \\
0 & \beta R & j_{3} & -q_{3} R \\
\gamma p q_{1} E & \gamma p q_{2} E & \gamma p q_{3} E & j_{4}
\end{array}\right],
$$

dengan

$$
\begin{aligned}
& j_{1}=r\left(1-\frac{2 P}{K}\right)-\alpha Q-q_{1} E, j_{2}=\alpha P-d_{1}-\beta R-q_{2} E, j_{3}=\beta Q-d_{2}-q_{3} E, \\
& j_{4}=\gamma\left[p\left(q_{1} P+q_{2} Q+q_{3} R\right)-c\right] .
\end{aligned}
$$

Untuk menganalisa kestabilan titik kesetimbangan, maka masing-masing titik kesetimbangan disubstitusikan ke matriks Jacobian.

Substitusi titik kesetimbangan trivial ke dalam matriks Jacobian (5) menghasilkan

$$
J(0,0,0,0)=\left[\begin{array}{cccc}
r & 0 & 0 & 0 \\
0 & -d_{1} & 0 & 0 \\
0 & 0 & -d_{2} & 0 \\
0 & 0 & 0 & -c \gamma
\end{array}\right]
$$

Sehingga dengan menyelesaikan persamaan $|J(0,0,0,0)-\lambda I|=0$ diperoleh persamaan karakteristik (6).

$$
\begin{aligned}
& \lambda^{4}+\left(-r+d_{1}+d_{2}+c \gamma\right) \lambda^{3}+\left(-r d_{1}-r d_{2}-r c \gamma+d_{1} d_{2}+d_{1} c \gamma+d_{2} c \gamma\right) \lambda^{2} \\
& +\left(-r d_{1} d_{2}-r c d_{1} \gamma-r c d_{2} \gamma+d_{1} d_{2} c \gamma\right) \lambda-r c d_{1} d_{2} \gamma=0,
\end{aligned}
$$

Tabel kriteria Routh-Hurwitz dari persamaan karakteristik (6) adalah

$$
\begin{array}{c|ccc}
\lambda^{4} & A_{0} & A_{2} & A_{4} \\
\lambda^{3} & A_{1} & A_{3} & \\
\lambda^{2} & B_{1} & A_{4} &
\end{array}
$$


dengan

$$
\begin{array}{l|l}
\lambda^{1} & C_{1} \\
\lambda^{0} & A_{4}
\end{array}
$$

$$
\begin{aligned}
& A_{0}=1, A_{1}=-r+d_{1}+d_{2}+c \gamma, A_{2}=-r d_{1}-r d_{2}-r c \gamma+d_{1} d_{2}+d_{1} c \gamma+d_{2} c \gamma, \\
& A_{3}=-r d_{1} d_{2}-r c d_{1} \gamma-r c d_{2} \gamma+d_{1} d_{2} c \gamma, A_{4}=-r c d_{1} d_{2} \gamma, B_{1}=\frac{A_{1} \cdot A_{2}-A_{3}}{A_{1}}, \text { dan } \\
& C_{1}=\frac{B_{1} \cdot A_{3}-A_{1} \cdot A_{4}}{B_{1}} .
\end{aligned}
$$

Sehingga titik kesetimbangan trivial bersifat stabil jika $A_{1} \geq 0, B_{1} \geq 0, C_{1} \geq 0$ dan $A_{4} \geq 0$.

Substitusi titik kesetimbangan $T^{0}\left(P^{0}, Q^{0}, R^{0}, 0\right)$ ke dalam matriks Jacobian (5) menghasilkan matriks (7).

$$
J\left(P^{0}, Q^{0}, R^{0}, 0\right)=\left[\begin{array}{cccc}
j_{01} & -\frac{\alpha K}{r}\left(r-\alpha \frac{d_{2}}{\beta}\right) & 0 & -\frac{q_{1} K}{r}\left(r-\alpha \frac{d_{2}}{\beta}\right) \\
\frac{\alpha d_{2}}{\beta} & j_{02} & -d_{2} & -\frac{q_{2} d_{2}}{\beta} \\
0 & \alpha \frac{K}{r}\left(r-\alpha \frac{d_{2}}{\beta}\right)-d_{1} & j_{03} & -\frac{q_{3}}{\beta}\left(\alpha \frac{K}{r}\left(r-\alpha \frac{d_{2}}{\beta}\right)-d_{1}\right) \\
0 & 0 & 0 & j_{04}
\end{array}\right],
$$

dengan

$$
\begin{aligned}
& j_{01}=-r+\frac{2 \alpha d_{2}}{\beta}, j_{02}=0, j_{03}=0, \\
& j_{04}=\frac{p q_{1} \gamma K r \beta^{2}-p q_{1} \alpha \gamma K d_{2} \beta+p q_{2} \gamma d_{2} r \beta+p q_{3} \alpha \gamma K r \beta-p q_{3} \alpha^{2} \gamma K d_{2}-p q_{3} \gamma d_{1} r \beta-\gamma c r \beta^{2}}{r \beta^{2}} .
\end{aligned}
$$

Penyelesaian $\left|J\left(P^{0}, Q^{0}, R^{0}, 0\right)-\lambda I\right|=0$ menghasilkan persamaan karakteristik (8).

$$
\begin{aligned}
& \lambda^{4}-\left(j_{01}+j_{04}\right) \lambda^{3}+\left(j_{01} j_{04}+\alpha K d_{2}-\frac{\alpha^{2} K d_{2}^{2}}{r \beta}+d_{1} d_{2}+\frac{\alpha^{2} K d_{2}}{\beta}-\frac{\alpha^{3} K d_{2}^{2}}{r \beta^{2}}\right) \lambda^{2} \\
& +\left(\frac{\alpha^{2} K d_{2}^{2} j_{01}}{r \beta}-\alpha K d_{2} j_{01}+d_{1} d_{2} j_{01}-\alpha K d_{2} j_{04}+\frac{\alpha^{2} K d_{2}^{2} j_{04}}{r \beta}+d_{1} d_{2} j_{04}\right. \\
& \left.-\frac{\alpha^{2} K j_{04} d_{2}}{\beta}+\frac{\alpha^{3} K j_{04} d_{2}^{2}}{r \beta^{2}}\right) \lambda+\alpha K d_{2} j_{01} j_{04}-\frac{\alpha^{2} K d_{2}^{2} j_{01} j_{04}}{r \beta}-d_{1} d_{2} j_{01} j_{04}=0,
\end{aligned}
$$

Tabel kriteria Routh-Hurwitz dari persamaan karakteristik (8) diberikan oleh tabel di bawah ini.

$$
\begin{array}{l|lll}
\lambda^{4} & a_{0} & a_{2} & a_{4} \\
\lambda^{3} & a_{1} & a_{3} &
\end{array}
$$




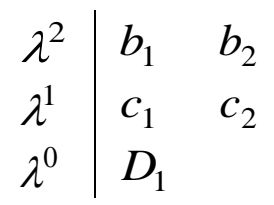

dengan

$$
\begin{aligned}
& a_{0}=1, a_{1}=-j_{01}-j_{04}, a_{2}=j_{01} j_{04}+d_{1} d_{2}+\alpha K d_{2}\left(1-\frac{\alpha d_{2}}{r \beta}+\frac{\alpha}{\beta}-\frac{\alpha^{2} d_{2}}{r \beta^{2}}\right), \\
& a_{3}=-\alpha K d_{2} j_{01}-\alpha K d_{2} j_{04}+d_{1} d_{2} j_{01}+d_{1} d_{2} j_{04}+\frac{\alpha^{2} K d_{2}}{\beta}\left(\frac{d_{2} j_{01}}{r}+\frac{d_{2} j_{04}}{r}-j_{04}+\frac{\alpha j_{04} d_{2}}{r \beta}\right) \text {, } \\
& a_{4}=d_{2} j_{01} j_{04}\left(\alpha K-\frac{\alpha^{2} K d_{2}}{r \beta}-d_{1}\right) \text {, } \\
& b_{1}=\frac{1}{r \beta^{2}}\left[-p q_{1} \gamma K r^{2} \beta^{2}+p q_{1} \alpha \gamma d_{2} r \beta-p q_{2} \gamma d_{2} r^{2} \beta-p q_{3} \alpha \gamma K r^{2} \beta+p q_{3} \alpha^{2} \gamma K d_{2} r+p q_{3} \gamma d_{1} r^{2} \beta\right. \\
& +\gamma c r^{2} \beta^{2}+2 d_{1} d_{2} r \beta^{2}+\alpha^{2} K d_{2} r \beta-\alpha^{3} K d_{2}{ }^{2}+2 p q_{1} \alpha \gamma K d_{2} r \beta-2 p q_{1} \alpha^{2} \gamma K d_{2}{ }^{2}+2 p q_{2} \alpha \gamma d_{2}{ }^{2} r \\
& +2 p q_{3} \alpha^{2} \gamma K d_{2} r-\frac{2 p q_{3} \alpha^{3} \gamma K d_{2}{ }^{2}}{\beta}-2 p q_{3} \alpha \gamma d_{1} d_{2} r-2 \alpha \gamma c d_{2} r \beta+\frac{1}{\psi}\left\{p q_{1} \alpha^{3} d_{2}{ }^{2} \gamma K^{2} r \beta^{2}\right. \\
& -p q_{1} \alpha^{4} K^{2} d_{2}{ }^{3} \gamma \beta+p q_{2} \alpha^{3} K d_{2}{ }^{3} \gamma r \beta+p q_{3} \alpha^{4} K^{2} d_{2}{ }^{2} \gamma r \beta-p q_{3} \alpha^{5} K^{2} d_{2}{ }^{3} \gamma-p q_{3} \alpha^{3} K d_{2}{ }^{2} \gamma d_{1} r \beta \\
& -\alpha^{3} K d_{2}{ }^{2} \gamma c r \beta^{2}-\alpha^{2} d_{2} p q_{1} \gamma K^{2} r^{2} \beta^{3}+\alpha^{3} K^{2} d_{2}{ }^{2} r \beta^{2} p q_{1} \gamma-\alpha^{2} K p q_{2} \gamma d_{2}{ }^{2} r^{2} \beta^{2} \\
& \left.\left.-\alpha^{3} K^{2} d_{2} r^{2} \beta^{2} p q_{3} \gamma+\alpha^{4} K^{2} d_{2}{ }^{2} r \beta p q_{3} \gamma+\alpha^{2} K d_{2} r^{2} \beta^{2} p q_{3} \gamma d_{1}+\alpha^{2} K d_{2} \gamma c r^{2} \beta^{3}\right\}\right] \text {, }
\end{aligned}
$$$$
\psi=-r^{2} \beta^{2}+2 \alpha d_{2} r \beta+p q_{1} \gamma K r \beta^{2}-p q_{1} \alpha \gamma K d_{2} \beta+p q_{2} \gamma d_{2} r \beta+p q_{3} \alpha \gamma K r \beta-p q_{3} \alpha^{2} \gamma K d_{2}
$$$$
-p q_{3} \gamma d_{1} r \beta-\gamma c r \beta^{2}
$$$$
b_{2}=\alpha K d_{2} j_{01} j_{04}-\frac{\alpha^{2} K d_{2}^{2} j_{01} j_{04}}{r \beta}-d_{1} d_{2} j_{01} j_{04} \text {, }
$$$$
c_{1}=\frac{\left(-\alpha K d_{2} r \beta^{2}+d_{1} d_{2} r \beta^{3} \alpha^{2} K d_{2}^{2}\right)\left(j_{01}+j_{04}\right)\left(1-\frac{j_{01} j_{04} r \beta^{2} \psi}{\xi \psi+\zeta}\right)+\alpha^{2} K d_{2} j_{04}\left(\alpha d_{2}-r \beta\right)}{r \beta^{2}},
$$$$
\xi=-p q_{1} \gamma K r^{2} \beta^{2}+p q_{1} \alpha \gamma d_{2} r \beta-p q_{2} \gamma d_{2} r^{2} \beta-p q_{3} \alpha \gamma K r^{2} \beta+p q_{3} \alpha^{2} \gamma K d_{2} r+p q_{3} \gamma d_{1} r^{2} \beta
$$$$
+\gamma c r^{2} \beta^{2}+2 d_{1} d_{2} r \beta^{2}+\alpha^{2} K d_{2} r \beta-\alpha^{3} K d_{2}^{2}+2 p q_{1} \alpha \gamma K d_{2} r \beta-2 p q_{1} \alpha^{2} \gamma K d_{2}{ }^{2}
$$$$
+2 p q_{2} \alpha \gamma d_{2}^{2} r+2 p q_{3} \alpha^{2} \gamma K d_{2} r-\frac{2 p q_{3} \alpha^{3} \gamma K d_{2}^{2}}{\beta}-2 p q_{3} \alpha \gamma d_{1} d_{2} r-2 \alpha \gamma c d_{2} r \beta,
$$$$
\zeta=p q_{1} \alpha^{3} d_{2}{ }^{2} \gamma K^{2} r \beta^{2}-p q_{1} \alpha^{4} K^{2} d_{2}{ }^{3} \gamma \beta+p q_{2} \alpha^{3} K d_{2}{ }^{3} \gamma r \beta+p q_{3} \alpha^{4} K^{2} d_{2}{ }^{2} \gamma r \beta
$$$$
-p q_{3} \alpha^{5} K^{2} d_{2}{ }^{3} \gamma-p q_{3} \alpha^{3} K d_{2}{ }^{2} \gamma d_{1} r \beta-\alpha^{3} K d_{2}{ }^{2} \gamma c r \beta^{2}-\alpha^{2} d_{2} p q_{1} \gamma K^{2} r^{2} \beta^{3}
$$$$
+\alpha^{3} K^{2} d_{2}{ }^{2} r \beta^{2} p q_{1} \gamma-\alpha^{2} K p q_{2} \gamma d_{2}{ }^{2} r^{2} \beta^{2}-\alpha^{3} K^{2} d_{2} r^{2} \beta^{2} p q_{3} \gamma
$$$$
+\alpha^{4} K^{2} d_{2}{ }^{2} r \beta p q_{3} \gamma+\alpha^{2} K d_{2} r^{2} \beta^{2} p q_{3} \gamma d_{1}+\alpha^{2} K d_{2} \gamma c r^{2} \beta^{3} \text {, }
$$ 
$c_{2}=0, \quad D_{1}=\alpha K d_{2} j_{01} j_{04}-\frac{\alpha^{2} K d_{2}^{2} j_{01} j_{04}}{r \beta}-d_{1} d_{2} j_{01} j_{04}$.

Berdasarkan kriteria Routh-Hurwitz, titik kesetimbangan sistem tanpa adanya penangkapan ikan $T^{0}\left(P^{0}, Q^{0}, R^{0}, 0\right)$ bersifat stabil jika pertidaksamaan (9), (10), (11) dan $\{(12)$ atau (13) atau (14) $\}$ berikut ini dipenuhi.

$$
\begin{aligned}
& r^{2} \beta^{2}+p q_{1} \alpha \gamma K d_{2} \beta+p q_{3} \alpha^{2} \gamma K d_{2}+p q_{3} \gamma d_{1} r \beta+\gamma c r \beta^{2} \geq 2 \alpha d_{2} r \beta+p q_{1} \gamma K r \beta^{2} \\
& +p q_{2} \gamma d_{2} r \beta+p q_{3} \alpha \gamma K r \beta \text {. } \\
& (\xi \psi+\zeta) \alpha^{2} K d_{2} j_{04}\left(\alpha d_{2}-r \beta\right) \geq \\
& \left(\alpha K d_{2} r \beta^{2}-d_{1} d_{2} r \beta^{3} \alpha^{2} K d_{2}^{2}\right)\left(j_{01}+j_{04}\right)\left(\xi \psi+\zeta-j_{01} j_{04} r \beta^{2} \psi\right) . \\
& \xi \psi+\zeta \geq 0 . \\
& 2 \alpha d_{2} \geq r \beta \text {. } \\
& \alpha K r \beta \geq \alpha^{2} K d_{2}+d_{1} r \beta .
\end{aligned}
$$

Sedangkan substitusi titik kesetimbangan bioekonomis $T^{*}\left(P^{*}, Q^{*}, R^{*}, E^{*}\right)$ ke matriks Jacobian (5) menghasilkan matriks

$$
J\left(P^{*}, Q^{*}, R^{*}, E^{*}\right)=\left[\begin{array}{llll}
j_{11}{ }^{*} & j_{12}{ }^{*} & j_{13}{ }^{*} & j_{14}{ }^{*} \\
j_{21}{ }^{*} & j_{22}{ }^{*} & j_{23}{ }^{*} & j_{24}{ }^{*} \\
j_{31}{ }^{*} & j_{32}{ }^{*} & j_{33}{ }^{*} & j_{34}{ }^{*} \\
j_{41}{ }^{*} & j_{42}{ }^{*} & j_{43}{ }^{*} & j_{44}{ }^{*}
\end{array}\right],
$$

dengan

$$
\begin{aligned}
& j_{11}{ }^{*}=r\left(1-\frac{2 P^{*}}{K}\right)-\alpha Q^{*}-q_{1} E^{*}, j_{12}{ }^{*}=-\frac{\alpha K}{r}\left(r-\frac{\alpha}{\beta}\left(d_{2}+q_{3} E^{*}\right)-q_{1} E^{*}\right), j_{13}{ }^{*}=0, \\
& j_{14}{ }^{*}=-\frac{q_{1} K}{r}\left(r-\frac{\alpha}{\beta}\left(d_{2}+q_{3} E^{*}\right)-q_{1} E^{*}\right), j_{21}{ }^{*}=\frac{\alpha d_{2}+q_{3} \alpha E^{*}}{\beta}, j_{22}{ }^{*}=0, \\
& j_{23}{ }^{*}=-d_{2}-q_{3} E^{*}, j_{24}{ }^{*}=\frac{-q_{2} d_{2}-q_{2} q_{3} E^{*}}{\beta}, j_{31}{ }^{*}=0, \\
& j_{32}{ }^{*}=\frac{\alpha K}{r}\left(r-\frac{\alpha}{\beta}\left(d_{2}+q_{3} E^{*}\right)-q_{1} E^{*}\right)-d_{1}-q_{2} E^{*}, j_{33}{ }^{*}=0,
\end{aligned}
$$




$$
\begin{aligned}
& j_{34}{ }^{*}=-\frac{q_{3} \alpha K}{\beta r}\left(r-\frac{\alpha}{\beta}\left(d_{2}+q_{3} E^{*}\right)-q_{1} E^{*}\right)+\frac{q_{3} d_{1}}{\beta}+\frac{q_{2} q_{3}}{\beta} E^{*}, \\
& j_{41}{ }^{*}=\frac{r p q_{1}\left(q_{1} K \beta^{2} r-q_{1} K \alpha \beta d_{2}+q_{2} d_{2} \beta r+q_{3} \alpha K \beta r-q_{3} \alpha^{2} K d_{2}-d_{1} \beta r\right)-\gamma q_{1} c \beta^{2} r}{\left(q_{1} K \alpha \beta q_{3}+q_{1}{ }^{2} \beta^{2} r K-q_{2} q_{3} \beta r+q_{3}{ }^{2} \alpha^{2} K+q_{3} q_{1} \alpha \beta K+q_{2} \beta r\right)}, \\
& j_{42}{ }^{*}=\frac{p p q_{2}\left(q_{1} K \beta^{2} r-q_{1} K \alpha \beta d_{2}+q_{2} d_{2} \beta r+q_{3} \alpha K \beta r-q_{3} \alpha^{2} K d_{2}-d_{1} \beta r\right)-\gamma q_{2} c \beta^{2} r}{\left(q_{1} K \alpha \beta q_{3}+q_{1}{ }^{2} \beta^{2} r K-q_{2} q_{3} \beta r+q_{3}{ }^{2} \alpha^{2} K+q_{3} q_{1} \alpha \beta K+q_{2} \beta r\right)}, \\
& j_{43}{ }^{*}=\frac{\gamma p q_{3}\left(q_{1} K \beta^{2} r-q_{1} K \alpha \beta d_{2}+q_{2} d_{2} \beta r+q_{3} \alpha K \beta r-q_{3} \alpha^{2} K d_{2}-d_{1} \beta r\right)-\gamma q_{3} c \beta^{2} r}{\left(q_{1} K \alpha \beta q_{3}+q_{1}{ }^{2} \beta^{2} r K-q_{2} q_{3} \beta r+q_{3}{ }^{2} \alpha^{2} K+q_{3} q_{1} \alpha \beta K+q_{2} \beta r\right)}, \\
& j_{44}{ }^{*}=\gamma\left[p\left(q_{1} P^{*}+q_{2} Q^{*}+q_{3} R^{*}\right)-c\right] .
\end{aligned}
$$

Kemudian dari penyelesaian persamaan $\left|J\left(P^{*}, Q^{*}, R^{*}, E^{*}\right)-\lambda I\right|=0$ dihasilkan persamaan karakteristik (16).

$$
\alpha_{0} \lambda^{4}+\alpha_{1} \lambda^{3}+\alpha_{2} \lambda^{2}+\alpha_{3} \lambda+\alpha_{4}=0
$$

dengan

$$
\begin{aligned}
\alpha_{0}= & 1, \alpha_{1}=-\left(j_{11}{ }^{*}+j_{44}{ }^{*}\right), \\
\alpha_{2}= & j_{11}{ }^{*} j_{44}{ }^{*}-j_{24}{ }^{*} j_{42}{ }^{*}-j_{23}{ }^{*} j_{32}{ }^{*}-j_{34}{ }^{*} j_{43}{ }^{*}-j_{12}{ }^{*} j_{21}{ }^{*}-j_{14}{ }^{*} j_{41}{ }^{*}, \\
\alpha_{3}= & j_{11}{ }^{*} j_{24}{ }^{*} j_{42}{ }^{*}+j_{11}{ }^{*} j_{23}{ }^{*} j_{32}{ }^{*}+j_{11}{ }^{*} j_{34}{ }^{*} j_{43}{ }^{*}-j_{23}{ }^{*} j_{34}{ }^{*} j_{42}{ }^{*}-j_{24}{ }^{*} j_{32}{ }^{*} j_{43}{ }^{*}+j_{23}{ }^{*} j_{32}{ }^{*} j_{44}{ }^{*} \\
& +j_{12}{ }^{*} j_{21}{ }^{*} j_{44}{ }^{*}-j_{12}{ }^{*} j_{24}{ }^{*} j_{41}{ }^{*}-j_{14}{ }^{*} j_{21}{ }^{*} j_{42}{ }^{*}, \\
\alpha_{4}= & j_{11}{ }^{*} j_{23}{ }^{*} j_{34}{ }^{*} j_{42}{ }^{*}+j_{11}{ }^{*} j_{24}{ }^{*} j_{32}{ }^{*} j_{43}{ }^{*}-j_{11}{ }^{*} j_{23}{ }^{*} j_{32}{ }^{*} j_{44}{ }^{*}-j_{12}{ }^{*} j_{23}{ }^{*} j_{34}{ }^{*} j_{41}{ }^{*} \\
& +j_{12}{ }^{*} j_{21}{ }^{*} j_{34}{ }^{*} j_{43}{ }^{*}-j_{14}{ }^{*} j_{21}{ }^{*} j_{32}{ }^{*} j_{43}{ }^{*}+j_{14}{ }^{*} j_{23}{ }^{*} j_{32}{ }^{*} j_{41}{ }^{*} \cdot
\end{aligned}
$$

Tabel kriteria Routh-Hurwitz untuk persamaan karakteristik (16) adalah sebagai berikut

\begin{tabular}{c|ccc}
$\lambda^{4}$ & $\alpha_{0}$ & $\alpha_{2}$ & $\alpha_{4}$ \\
$\lambda^{3}$ & $\alpha_{1}$ & $\alpha_{3}$ & \\
$\lambda^{2}$ & $\beta_{1}$ & $\beta_{2}$ & \\
$\lambda^{1}$ & $\chi_{1}$ & $\chi_{2}$ & \\
$\lambda^{0}$ & $\delta_{1}$ & &
\end{tabular}

dengan 


$$
\begin{aligned}
& \beta_{1}=\frac{\tau}{\left(j_{11}^{*}+j_{44}^{*}\right)}, \\
& \tau=j_{11}{ }^{* 2} j_{44}{ }^{*}-j_{11}{ }^{*} j_{24}{ }^{*} j_{42}{ }^{*}-j_{11}{ }^{*} j_{23}{ }^{*} j_{32}{ }^{*}-j_{11}{ }^{*} j_{34}{ }^{*} j_{43}{ }^{*}-j_{11}{ }^{*} j_{12}{ }^{*} j_{21}{ }^{*}-j_{11}{ }^{*} j_{14}{ }^{*} j_{41}{ }^{*} \\
& +j_{11}{ }^{*} j_{44}{ }^{* 2}-j_{24}{ }^{*} j_{42}{ }^{*} j_{44}{ }^{*}-j_{23}{ }^{*} j_{32}{ }^{*} j_{44}{ }^{*}-j_{34}{ }^{*} j_{43}{ }^{*} j_{44}{ }^{*}-j_{12}{ }^{*} j_{21}{ }^{*} j_{44}{ }^{*}-j_{14}{ }^{*} j_{41}{ }^{*} j_{44}{ }^{*} \\
& +j_{11}{ }^{*} j_{24}{ }^{*} j_{42}{ }^{*}+j_{11}{ }^{*} j_{23}{ }^{*} j_{32}{ }^{*}+j_{11}{ }^{*} j_{34}{ }^{*} j_{43}{ }^{*}-j_{23}{ }^{*} j_{34}{ }^{*} j_{42}{ }^{*}-j_{24}{ }^{*} j_{32}{ }^{*} j_{43}{ }^{*}+j_{23}{ }^{*} j_{32}{ }^{*} j_{44}{ }^{*} \\
& +j_{12}{ }^{*} j_{21}{ }^{*} j_{44}{ }^{*}-j_{12}{ }^{*} j_{24}{ }^{*} j_{41}{ }^{*}-j_{14}{ }^{*} j_{21}{ }^{*} j_{42}{ }^{*}, \\
& \beta_{2}=j_{11}{ }^{*} j_{23}{ }^{*} j_{34}{ }^{*} j_{42}{ }^{*}+j_{11}{ }^{*} j_{24}{ }^{*} j_{32}{ }^{*} j_{43}{ }^{*}-j_{11}{ }^{*} j_{23}{ }^{*} j_{32}{ }^{*} j_{44}{ }^{*}-j_{12}{ }^{*} j_{23}{ }^{*} j_{34}{ }^{*} j_{41}{ }^{*} \\
& +j_{12}{ }^{*} j_{21}{ }^{*} j_{34}{ }^{*} j_{43}{ }^{*}-j_{14}{ }^{*} j_{21}{ }^{*} j_{32}{ }^{*} j_{43}{ }^{*}+j_{14}{ }^{*} j_{23}{ }^{*} j_{32}{ }^{*} j_{41}{ }^{*} \text {, } \\
& \chi_{1}=\frac{1}{\tau}\left[\tau \alpha_{3}+\alpha_{1}^{2} \beta_{2}\right], \chi_{2}=0 \text {, } \\
& \delta_{1}=j_{11}{ }^{*} j_{23}{ }^{*} j_{34}{ }^{*} j_{42}{ }^{*}+j_{11}{ }^{*} j_{24}{ }^{*} j_{32}{ }^{*} j_{43}{ }^{*}-j_{11}{ }^{*} j_{23}{ }^{*} j_{32}{ }^{*} j_{44}{ }^{*}-j_{12}{ }^{*} j_{23}{ }^{*} j_{34}{ }^{*} j_{41}{ }^{*} \\
& +j_{12}{ }^{*} j_{21}{ }^{*} j_{34}{ }^{*} j_{43}{ }^{*}-j_{14}{ }^{*} j_{21}{ }^{*} j_{32}{ }^{*} j_{43}{ }^{*}+j_{14}{ }^{*} j_{23}{ }^{*} j_{32}{ }^{*} j_{41}{ }^{*} \text {. }
\end{aligned}
$$

Dengan demikian, berdasarkan kriteria Routh-Hurwitz, titik kesetimbangan $T=\left(P^{*}, Q^{*}, R^{*}, E^{*}\right)$ adalah stabil jika memenuhi pertaksamaan (17)-(20).

$$
\begin{gathered}
j_{11}{ }^{*}+j_{44}{ }^{*} \leq 0 . \\
\tau<0 . \\
\tau \alpha_{3}+\alpha_{1}{ }^{2} \beta_{2} \leq 0 . \\
j_{11}{ }^{*} j_{23}{ }^{*} j_{34}{ }^{*} j_{42}{ }^{*}+j_{11}{ }^{*} j_{24}{ }^{*} j_{32}{ }^{*} j_{43}{ }^{*}+j_{12}{ }^{*} j_{21}{ }^{*} j_{34}{ }^{*} j_{43}{ }^{*}+j_{14}{ }^{*} j_{23}{ }^{*} j_{32}{ }^{*} j_{41}{ }^{*} \geq \\
j_{11}{ }^{*} j_{23}{ }^{*} j_{32}{ }^{*} j_{44}{ }^{*}+j_{12}{ }^{*} j_{23}{ }^{*} j_{34}{ }^{*} j_{41}{ }^{*}+j_{14}{ }^{*} j_{21}{ }^{*} j_{32}{ }^{*} j_{43}{ }^{*} .
\end{gathered}
$$

\subsection{Simulasi Numerik}

Nilai parameter yang digunakan dalam simulasi numerik disajikan dalam Tabel 1. Dengan menggunakan nilai parameter-parameter tersebut, diperoleh titik kesetimbangan tanpa penangkapan ikan $T^{0}(0.9798,6.2500 \mathrm{e}-004,0.6111,0)$ dan titik kesetimbangan bioekonomis $T^{*}$ (0.9126, 0.1378, 0.5234, 1.8292). Melalui perhitungan MATLAB, diketahui bahwa nilai parameter-parameter pada Tabel 1 tidak memenuhi syarat kestabilan titik kesetimbangan tanpa penangkapan ikan maupun titik kesetimbangan bioekonomis. Oleh karena itu, perilaku solusi sistem tidak akan stabil menuju titik kestabilan $T^{0}$ dan $T^{*}$.

Tabel 1. Nilai Parameter dalam Simulasi Numerik

\begin{tabular}{cc}
\hline Parameter & Nilai \\
\hline$r$ & 1.8 \\
$K$ & 0.98
\end{tabular}




\begin{tabular}{cc}
$\alpha$ & 0.5 \\
$\beta$ & 0.8 \\
$\gamma$ & 0.25 \\
$d_{1}$ & 0.001 \\
$d_{2}$ & 0.0005 \\
$p$ & 13 \\
\hline
\end{tabular}

Tanpa adanya tindakan penangkapan ikan, tidak akan ada ikan yang tertangkap dan tidak ada biaya operasional yang dikeluarkan oleh nelayan. Oleh karena itu, pada simulasi model pertumbuhan populasi ikan tanpa penangkapan, digunakan nilai parameter $q_{1}=q_{2}=q_{3}=c=0$. Pada simulasi tanpa penangkapan ikan, digunakan kondisi awal dari populasi prey adalah 7.1, populasi predator tingkat I adalah 3.8, populasi predator tingkat II adalah 1.6, dan hasil tangkapan nelayan adalah 0. Gambar 3 menunjukkan perilaku solusi sistem (1)-(4) tanpa adanya penangkapan ikan. Tanpa adanya penangkapan ikan, populasi predator tingkat I terus menurun sampai akhirnya mencapai nilai nol. Populasi predator tingkat II setelah mengalami peningkatan dari populasi awal menjadi 6.1322, mengalami penurunan sampai mencapai 6.0678. Populasi prey yang setelah mengalami penurunan, mengalami peningkatan dari nilai 0.3307 menjadi 0.3399 . Sedangkan hasil tangkapan nelayan, konstan bernilai nol.

Perilaku solusi sistem pada Gambar 3 disebabkan oleh nilai parameter $\beta>\alpha$. Oleh karena laju pemangsaan predator tingkat II terhadap predator tingkat I $(\beta)$ adalah lebih besar daripada laju pemangsaan predator I terhadap prey $(\alpha)$. Maka tanpa adanya penangkapan ikan, populasi predator tingkat II sebagai pemangsa yang menempati posisi paling tinggi pada piramida makanan, menjadi maksimal. Akibatnya, populasi predator tingkat I, sebagai mangsa dari predator tingkat II, menjadi semakin menurun. Dengan penurunan populasi predator tingkat I, populasi prey mengalami peningkatan. 


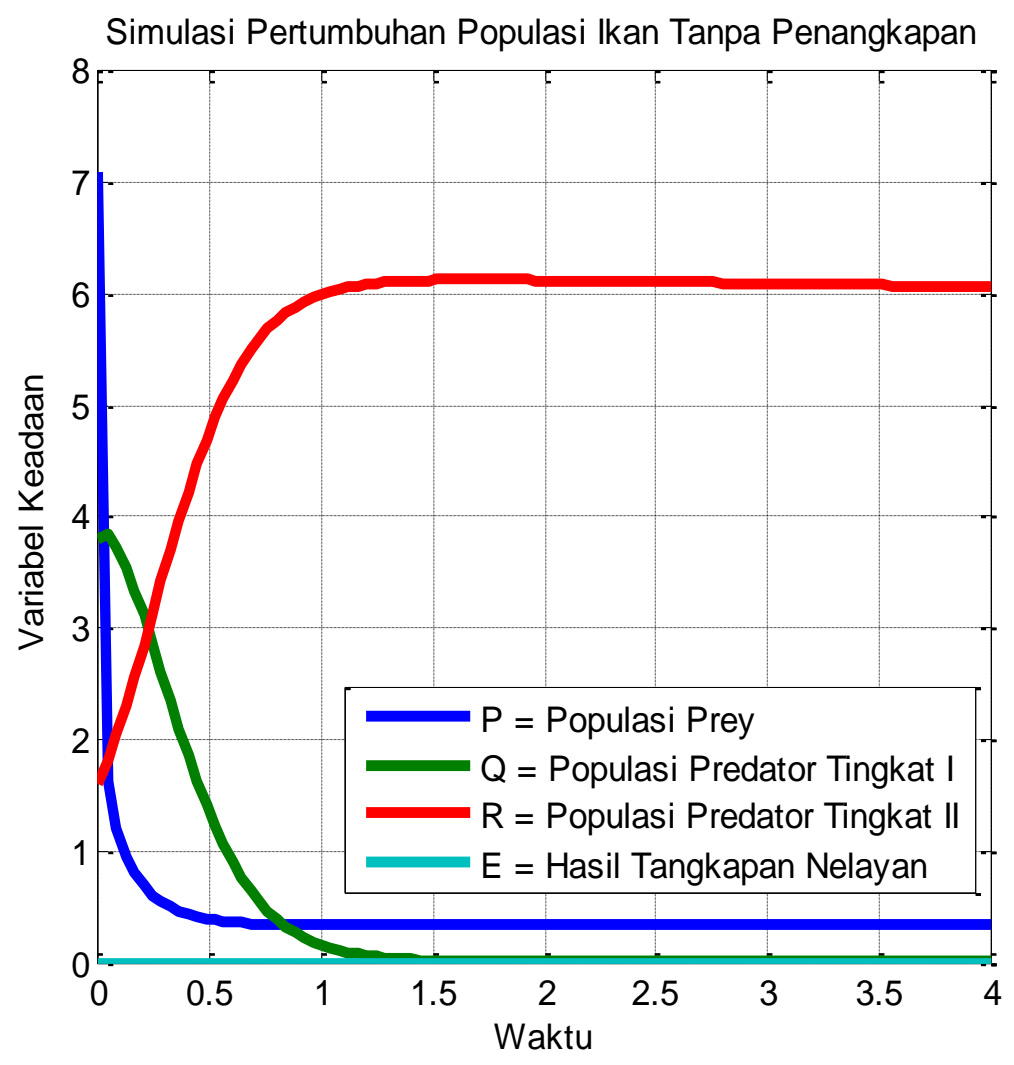

Gambar 3 Simulasi Pertumbuhan Populasi Ikan Tanpa Adanya Penangkapan

Dalam simulasi model dengan penangkapan ikan, digunakan kondisi awal populasi prey, predator tingkat I, dan tingkat II yang sama, yaitu 7.1, 3.8, dan 1.6, tetapi dengan hasil tangkapan nelayan mula-mula yang berbeda, yaitu $E_{0}=3$, dan nilai parameter $q_{1}=0.03, q_{2}=0.02, q_{3}=0.06$, $c=0.8$. 


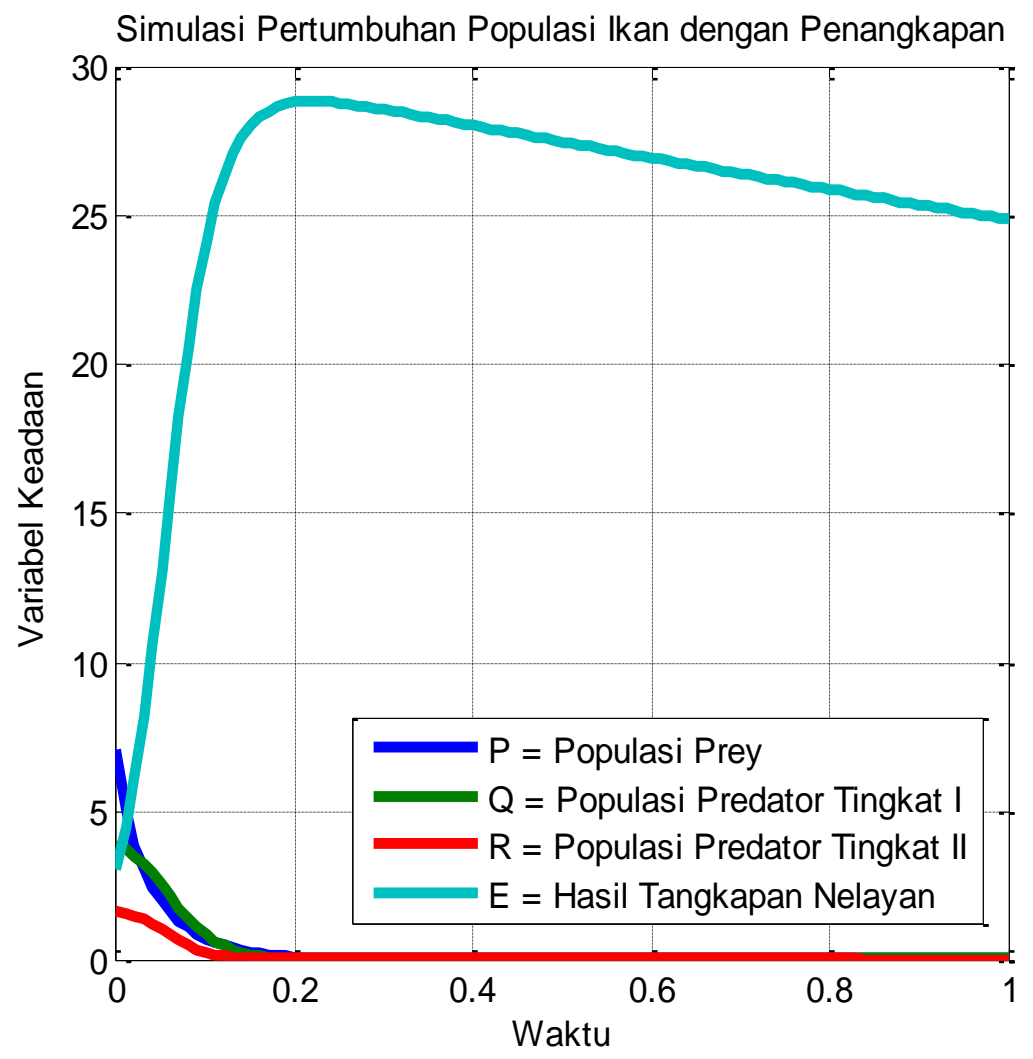

(a)

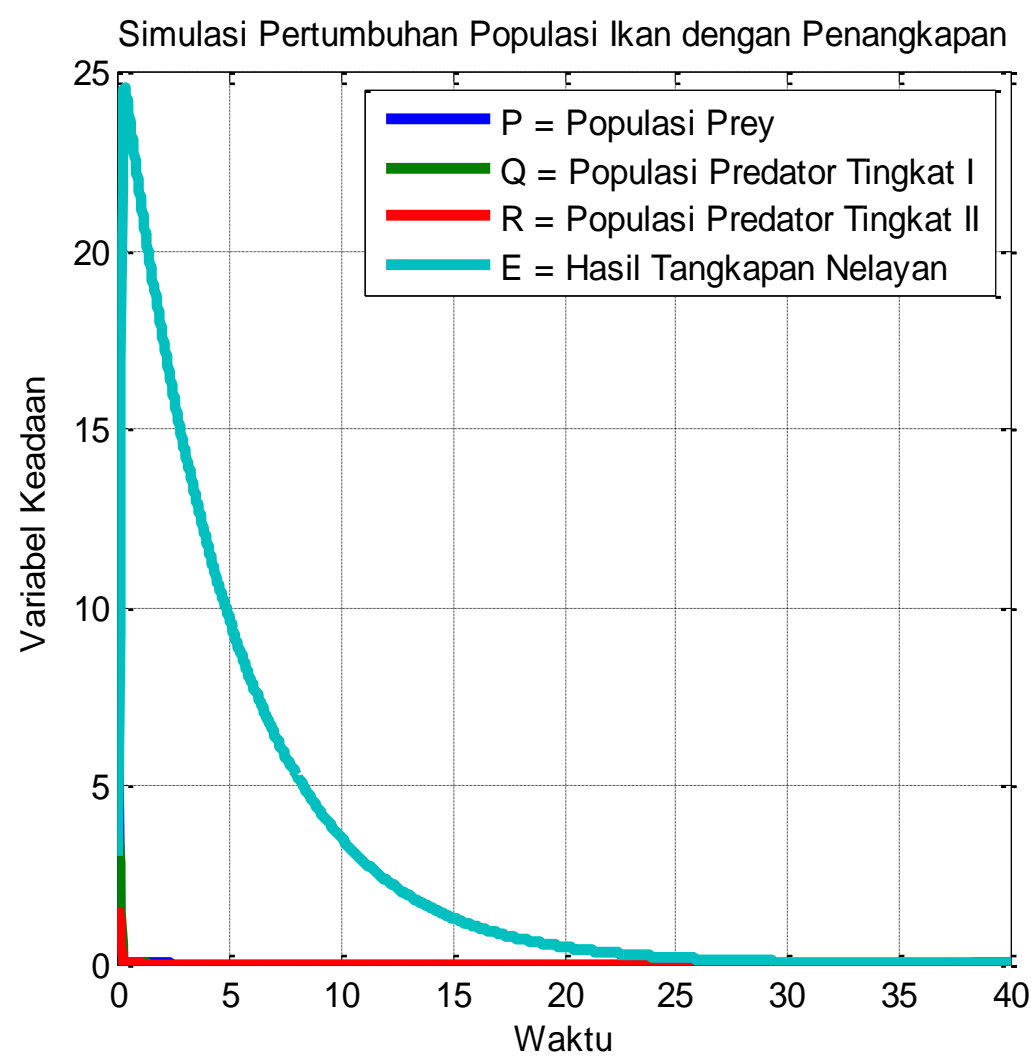

(b)

Gambar 4 Simulasi Pertumbuhan Populasi Ikan dengan Penangkapan Oleh Nelayan 
Gambar 4 menunjukkan perilaku solusi sistem (1)-(4) dengan penangkapan. Adanya penangkapan ikan oleh nelayan, dengan tingkat tertangkapnya ikan sebesar 3\% untuk prey, $2 \%$ untuk predator tingkat I, dan 6\% untuk predator tingkat II, mengakibatkan populasi semua ikan, baik prey, predator tingkat I dan II mengalami penurunan sampai akhirnya mencapai titik nol dan hasil tangkapan nelayan mencapai nilai tertinggi $E=24.6218$. Ketiadaan stok ikan, mengakibatkan tidak adanya tangkapan ikan. Hal ini ditunjukkan oleh grafik nilai $E$ yang terus menurun dan akhirnya mencapai titik nol.

\section{Simpulan}

Berdasarkan hasil dan pembahasan, dapat disimpulkan bahwa:

- Sistem penangkapan ikan dengan mempertimbangkan interaksi predator-prey bertingkat dan pendapatan nelayan dapat dimodelkan secara matematis.

- Model matematika yang dibangun mempunyai tiga titik kesetimbangan, yaitu titik kesetimbangan trivial, titik kesetimbangan tanpa adanya penangkapan ikan dan titik kesetimbangan bioekonomis. Ketiga titik kesetimbangan bersifat stabil bersyarat.

- Hasil simulasi menunjukkan bahwa tidak adanya penangkapan ikan dapat mengakibatkan ketidakseimbangan populasi ikan yang ditandai oleh kepunahan predator tingkat I yang mengakibatkan kepunahan predator tingkat II. Sedangkan penangkapan ikan yang tidak terkondisikan, yakni yang tidak memenuhi syarat kestabilan titik kesetimbangan bioekonomis, dapat mengarah ke kepunahan seluruh populasi ikan.

- Penelitian selanjutnya dapat membahas strategi penangkapan ikan yang optimal agar populasi ikan dapat terjaga dan berkembangbiak secara optimal. Selain itu, pada penelitian selanjutnya dapat digunakan parameter-parameter yang mengacu pada data sesungguhnya.

\section{Ucapan Terima Kasih}

Ucapan terima kasih dihaturkan kepada Kepala Pelabuhan Perikanan Nusantara Brondong beserta staf, dan para nelayan pesisir Lamongan yang telah memberikan informasi terkait sistem penangkapan ikan, alat tangkap dan hasil tangkapan ikan di kawasan setempat.

\section{Daftar Pustaka}

[1] H. Hazliansyah dan O. Lukmansyah, Pemanfaatan Potensi Ikan Laut Jawa Melampaui Batas. Dipetik 11 April 2017, dari Republika Online: http://www.republika.co.id/berita/nasional/daerah/15/03/24/nlpkty-pemanfaatan-potensi- 
ikan-laut-jawa-melebihi-batas, 24 Maret 2015.

[2] D. Sutisna, Profil Pelabuhan Perikanan Nusantara Brondong Tahun 2017. PPN Brondong, 2018.

[3] S. K. Widodo, "Dinamika Kebijakan Tentang Perikanan dan Transformasi Budaya Nelayan Pantai Utara Jawa," Sabda, vol. 6, no. 1, pp. 30-39, 2011.

[4] K. I. Suniada, F. Islamy, A. J. Saputra, S. Hadianti, R. M. P. Mahardhika, dan E. Susilo, "Dinamika Oseanografi Terhadap Hasil Tangkapan Ikan Pelagis PPN Pengambengan dari Data Satelit MODIS, ” Prosiding Seminar Nasional Penginderaan Jauh 2015, 2015.

[5] S. B. Susilo, "Kondisi Stok Ikan Perairan Pantai Selatan Jawa Barat,” Jurnal Ilmu-ilmu Perairan dan Perikanan Indonesia, vol. 16, no. 1, pp. 39-46, 2009.

[6] J. Murray, Mathematical Biology I: An Introduction. Springer, 2002.

[7] S. Chakraborty, S. Pal, dan N. Bairagi, "Predator-Prey Interaction with Harvesting: Mathematical Study with Biological Ramifications, ”Applied Mathematical Modelling 36, pp. 4044-4059, 2012.

[8] N. C. Apreutesei. "An Optimal Control Problem for a Prey-Predator System with a General Functional Response," Applied Mathematics Letters 22, pp. 1062-1065, 2009.

[9] L. Yunfei, R. Yuan, dan Y. Pei, "A Prey-Predator Model with Harvesting for Fishery Resource with Reserve Area,” Applied Mathematical Modelling 37, pp. 3048-3062, 2013.

[10] B. Mondal, "Bio-mathematical Prey-Predator Model with Marine Protect Area (MPA) and Harvesting," International Journal of Scientific \& Engineering Research, vol. 5, issue 9, pp. 858-868, 2014.

[11] S. K. Chattopadhyay dan T. K. Kar, “A Dynamic Reaction Model of a Prey-predator System with Stage-structure for Predator,” Modern Applied Science, pp. 183-195, 2010.

[12] K. Chakraborty, M. Chakraborty dan T. K. Kar, "Optimal Control of Harvest and Bifurcation of a Prey-Predator Model with Stage Structure," Applied Mathematics and Computation 217, pp. 8778-8792, 2011.

[13] T. K. Kar dan B. Gosh, "Impacts of Maximum Sustainable Yield Policy to Prey-predator Systems," Ecological Modelling 250, pp. 134-142. 2013.

[14] Subiono, Sistem Linear dan Kontrol Optimal. Institut Teknologi Sepuluh Nopember, 2013.

[15] D. K. Chaturvedi, Modeling and Simulation of Systems Using MATLAB and Simulink. CRC Press, 2010.

[16] Tim Rekap Data PPN Brondong, Data Kapal Bongkar Pelabuhan Perikanan Nusantara Brondong Januari 2018 (WPP 712). PPN Brondong, 2018. 